Гапріндашвілі Н. А., кандидат сільськогосподарських наук

Таврійський державний агротехнологічний університет

\title{
ЗМІНА АНТИОКИСЛЮВАЛЬНОГО КОМПЛЕКСУ В ПЛОДАХ ГРУШ
}

\section{Рецензент - кандидат сільськогосподарських наук В. М. Соколова}

Досліджено вплив післязбиральної обробки композиціями природних антиоксидантів на зміни антиокислювального комплексу в плодах груші за тривалого зберігання. Встановлено, щзо обробка плодів антиоксидантними композиціями тальмує окисновідновні прочеси й регулює неферментативні та ферментативні системи антиоксидантного захисту. Водночас зберігається запас тканинних антиоксидантів, щзо впливає на збереження плодами антиоксидантних властивостей. Екзогенне введення біогенних антиоксидантів фенольного типу сприяє циим процесам, підтримуючи енертетичний запас клітин.

Ключові слова: плоди груші, антиоксидантні композииї, ферменти, пероксидаза, поліфенолоксидаза.

Постановка проблеми. За даними Діксона М., Уэбба Э. [3], лежкість плодів залежить від інтенсивності окислювально-відновних процесів, що проявляється в інтенсивності дихання та активності ферментів пероксидази і поліфенолоксидази. В окислювально-відновних процеcax, що відбуваються в клітині, ці ферменти виконують роль каталізаторів і регулювальників усіх біохімічних процесів, що відбуваються. Зокрема, фермент окислювально-відновних реакцій пероксидаза, наявний у мітохондріях клітини, бере участь в іiі енергетичному обміні, утворенні етилену, регулює процеси дозрівання й старіння плодів. Активізація пероксидази відбувається в разі змін і порушень метаболізму рослин, а у випадку відповіді на стрес синтезується de novo.

Аналіз основних досліджень і публікацій, у яких започатковано розв'язання проблеми. $\mathrm{y}$ цьому напрямі особливого значення набуває використання антиоксидантних препаратів для подовження зберігання, що здатні потенціювати ендогенні захисні системи та збільшувати резистентність плодів у період зберігання.

Дія стрес-факторів збільшує швидкість окисно-відновних процесів, які відбуваються в плодах, іде більша витрата тканинних біологічноактивних речовин, у результаті чого втрачається якість продукції [5]. Для підвищення адаптостатусу плодів за тривалого зберігання найкращим стає шлях створення нових технологій на базі існуючих, які здатні підвищити адаптивний потенціал рослин та активізувати його захисні механізми [4].

Значне гальмування активності ферменту композиціями антиоксидантів, на думку В. В. Рогожина [6], пояснюється тим, що в коло пероксидазних субстратів ферменту входять різні функціонально активні речовини, в тому числі й антиоксиданти. В реакціях індивідуального окислення ці сполуки найчастіше $є$ повільно окислюємими субстратами. Високі концентрації антиоксидантів інгібують пероксидазу як у реакціях індивідуального, так і спільного окислення, здійснюючи таким чином регуляторну функцію.

Мета дослідження: вивчення впливу післязбиральної обробки природними антиоксидантами на зміни антиокислювального комплексу в плодах груші за тривалого зберігання.

Завдання дослідження: дослідити й дати теоретичне обгрунтування впливу діючих речовин антиоксидантних композицій на окисно-відновні процеси.

Матеріал і методика досліджень. Дослідження проводились у Таврійському державному агротехнологічному університеті та на виробничій базі Інституту зрошуваного садівництва ім. М. Ф. Сидоренка УААН (м. Мелітополь).

Плоди груші сорту Деканка зимова були закладені на зберігання в знімальному ступені стиглості [1]. Визначення календарної дати знімання проводилося за стандартними методиками. Перед закладанням на зберігання проводили інспекцію, сортування й калібрування плодів згідно 3 вимогами ГСТУ [2]. На зберігання закладалися плоди першого товарного сорту. Після цього плоди груші транспортували у плодосховище-холодильник на відстань 2 км згідно із ДСТУ ISO [8]. Обробка плодів проводилася шляхом занурення їх у свіжоприготовлені робочі розчини антиоксидантних композицій відразу після надходження у сховище. Варіанти обробки: 1) контроль - плоди без обробки (К(БО)); 2) контроль - плоди, оброблені 
водою (К(В)); 3) гліцерин - $1 \%$, екстракт із виноградної кісточки - решта (ВКГ); 4) лецитин - $4 \%$, екстракт із виноградної кісточки - решта (ВКЛ); 5) аскорбінова кислота - 0,5\%, рутин $0,5 \%$, гліцерин - $1 \%$, вода - решта (АКРГ); 6) аскорбінова кислота $-0,5 \%$, рутин $-0,5 \%$, лецитин $-4 \%$, вода - решта (АКРЛ).

Після обробки плоди висушували активним вентилюванням i укладали в заздалегідь промарковані ящики №53 згідно з ГОСТ [7]. Температура зберігання становить $0 \pm 2{ }^{\circ} \mathrm{C}$, відносна вологість повітря - $95 \%$. Ревізували плоди 5 разів.

Результати досліджень. Комплекс «пероксидаза - фенол-хінони - поліфенолоксидаза» становить один $з$ активних фізіологічних механізмів, що бере участь у захисті рослин від уражень. Обробка біогенними антиоксидантами дає можливість у процесі зберігання активувати пероксидазу й інгібірувати поліфенолоксидазу плодів груші. Поліфенолоксидаза - малоспецифічний фермент, у рослинах переважно каталізує процес окислення поліфенолів у хінони.

Як видно 3 результатів досліджень (рис. 1), активність поліфенолоксидази знижувалася в плодах усіх варіантів обробки до мінімуму в період клімактериксу. В цей час у плодах відбувалося накопичення фенольних сполук, плоди набували характерного забарвлення, смаку та аромату. За зберігання плодів груші сорту Вікторія до 90-ї доби характер зміни активності ферменту поліфенолоксидази був практично однаковий як в оброблених плодах, так і в контрольному варіанті. У плодах груші Вікторія мінімальне значення активності ферменту поліфенолоксидази спостерігалося на 90-у добу зберігання за обробки композиціями АКРГ та АКРЛ і становила 9,38-10,26 мкМ/хв. За подальшого зберігання відбувається збільшення ферменту, але наприкінці зберігання цей показник був нижче контрольного варіанту в середньому в 2,1 разу. Динаміка активності поліфенолоксидази у плодів груші сорту Деканка зимова була спадаючою незалежно від складу композицій. Обробка плодів природними антиоксидантами значно знизила активність ферменту й була мінімальною у варіантах АКРГ, АКРЛ на 170-у добу зберігання (рис. 2). За тривалішого зберігання плодів активність поліфенолоксидази підвищувалася. Обробка плодів природними антиоксидантами дає можливість у процесі зберігання знизити активність поліфенолоксидази. Нами проводилися дослідження динаміки активності пероксидази у плодах груші сортів Вікторія та Деканка зимова, оброблених антиоксидантними композиціями. За зберігання в плодах груші сорту Вікторія зниження активності ферменту пероксидаза спостерігалося в усіх варіантах, оброблених антиоксидантними композиціями (рис. 3).

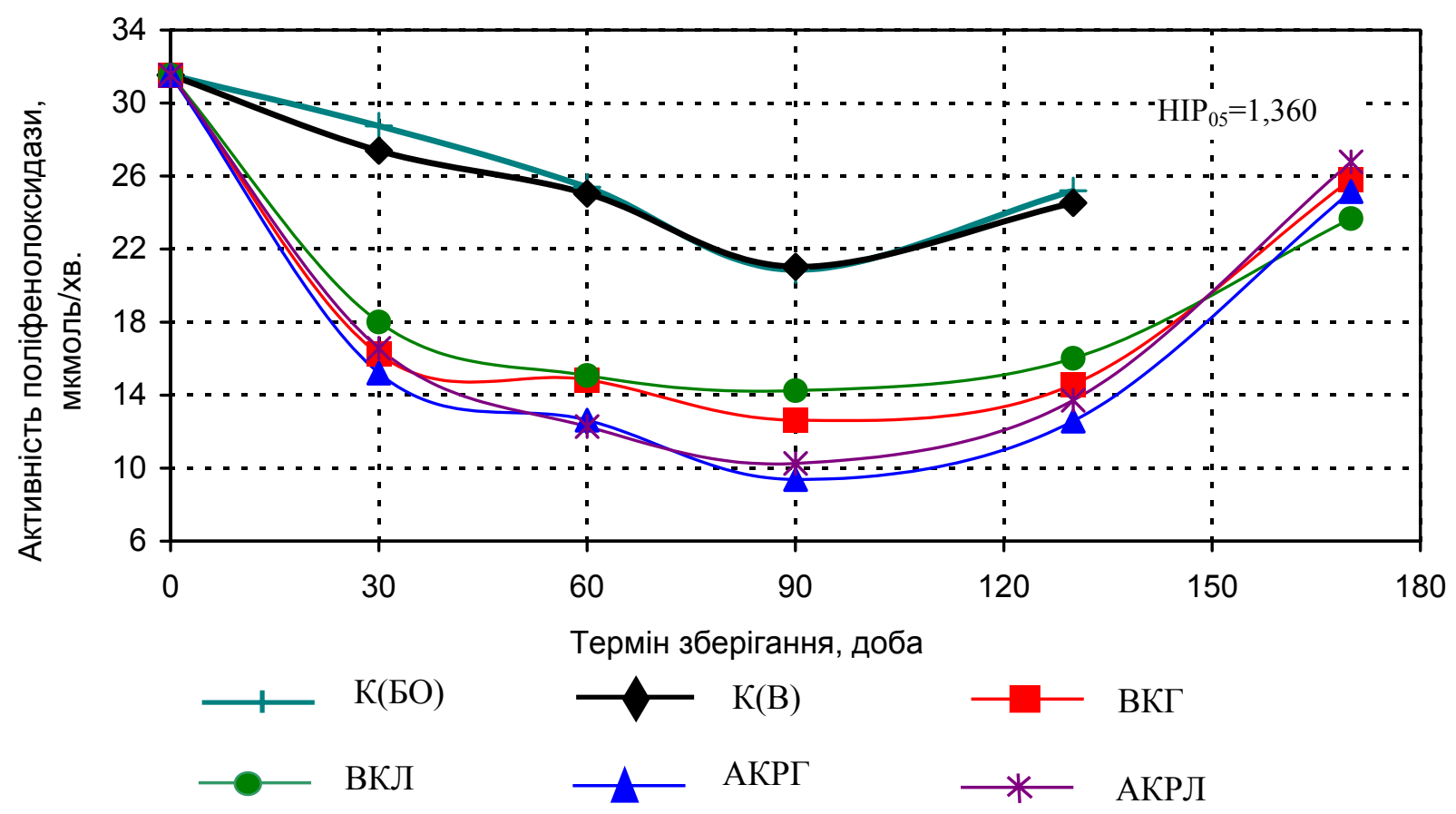

Рис. 1. Активність поліфенолоксидази в плодах груші сорту Вікторія, оброблених антиоксидантами, мкмоль/хв 


\section{СІЛЬСЬКЕ ГОСПОДАРСТВО. РОСЛИННИЦТВО}

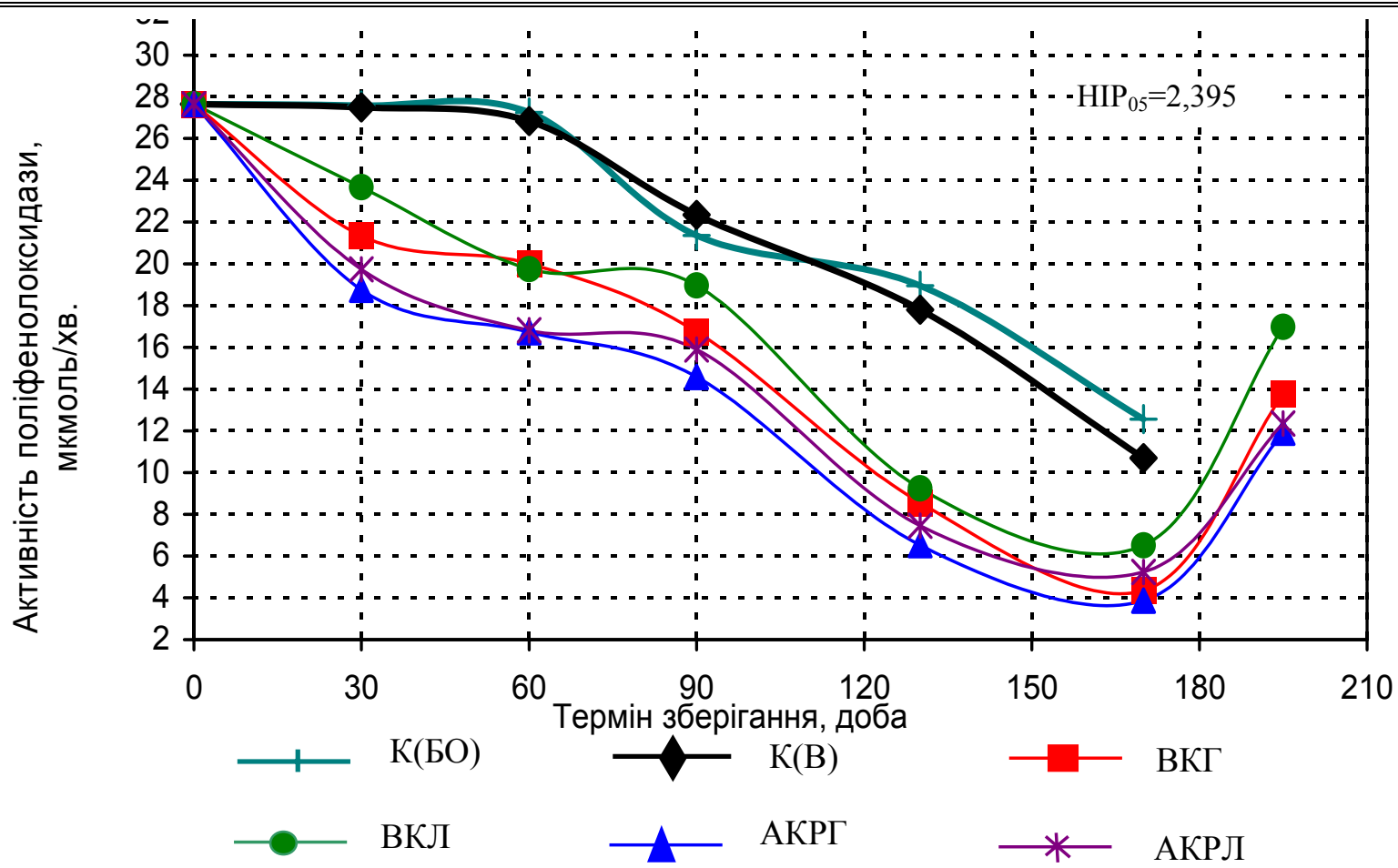

Рис. 2. Активність поліфенолоксидази в плодах груші сорту Деканка зимова, оброблених антиоксидантами, мкмоль/хв

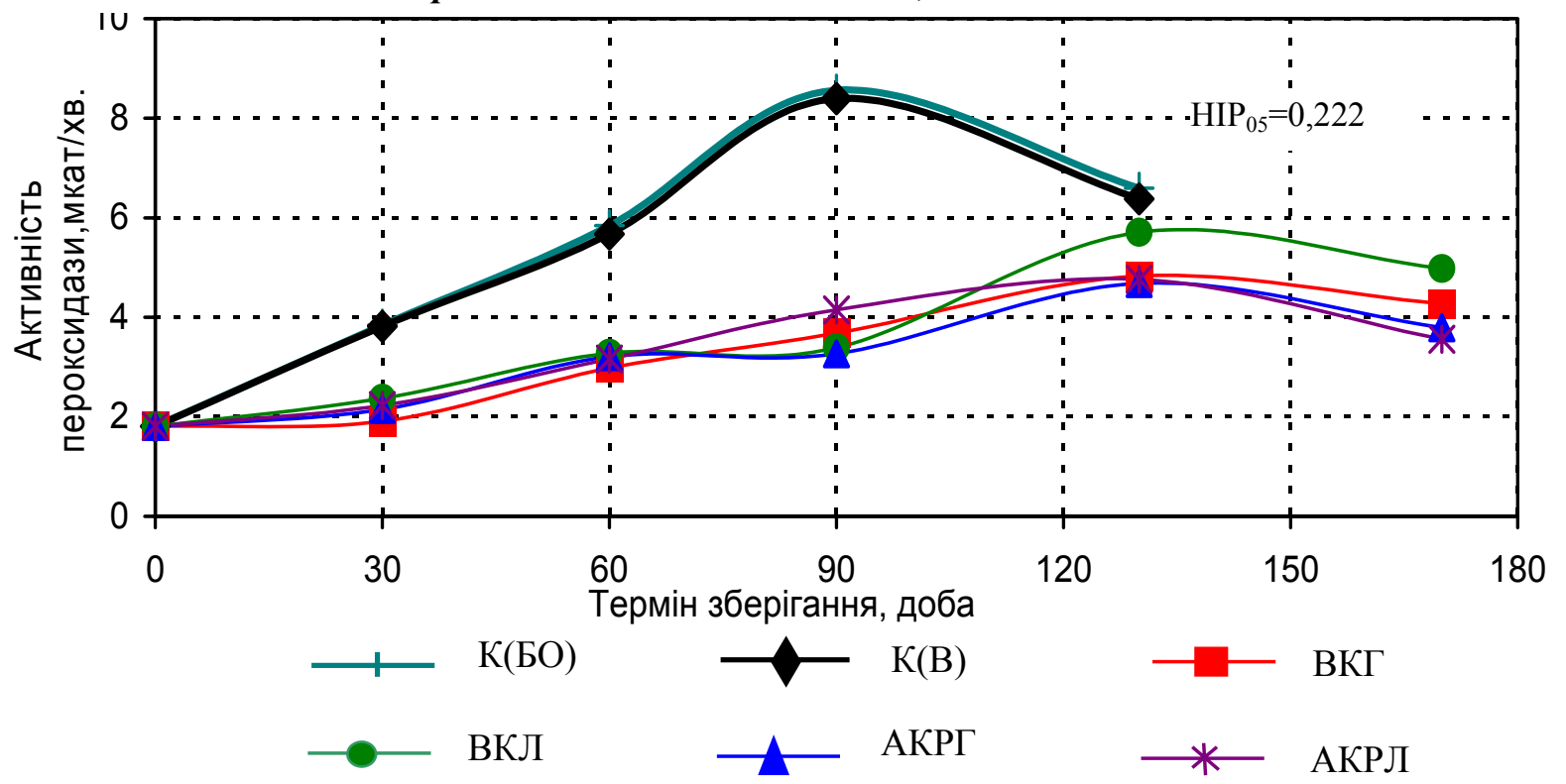

Рис. 3. Пероксидазна активність плодів груші сорту Вікторія, оброблених антиоксидантами, мкат/хв

Максимальне збільшення активності спостерігалося на 90-у добу зберігання у контрольному варіанті, що становило 8,56 мкат/хв. У цілому обробка антиоксидантними препаратами виявила гальмування ферменту. Наприкінці зберігання (170-а доба) пероксидазна активність у плодах, оброблених антиоксидантною композицією, була в середньому в 1,7 разу нижчою, ніж у контрольному варіанті.

Максимальне значення активності ферменту в плодах груші сорту Деканка зимова спостерігали у контрольному варіанті (плоди без обробки), що становило 17,09 мкат/хв (рис. 4). Пік активності ферменту спадав на 130-у добу зберігання. За весь період зберігання найменша активність ферменту спостерігалась у варіантах АКРГ та ВКГ і була нижчою за контроль у середньому у 2,7 разу на 130 -у добу зберігання й удвічі - наприкінці зберігання. 


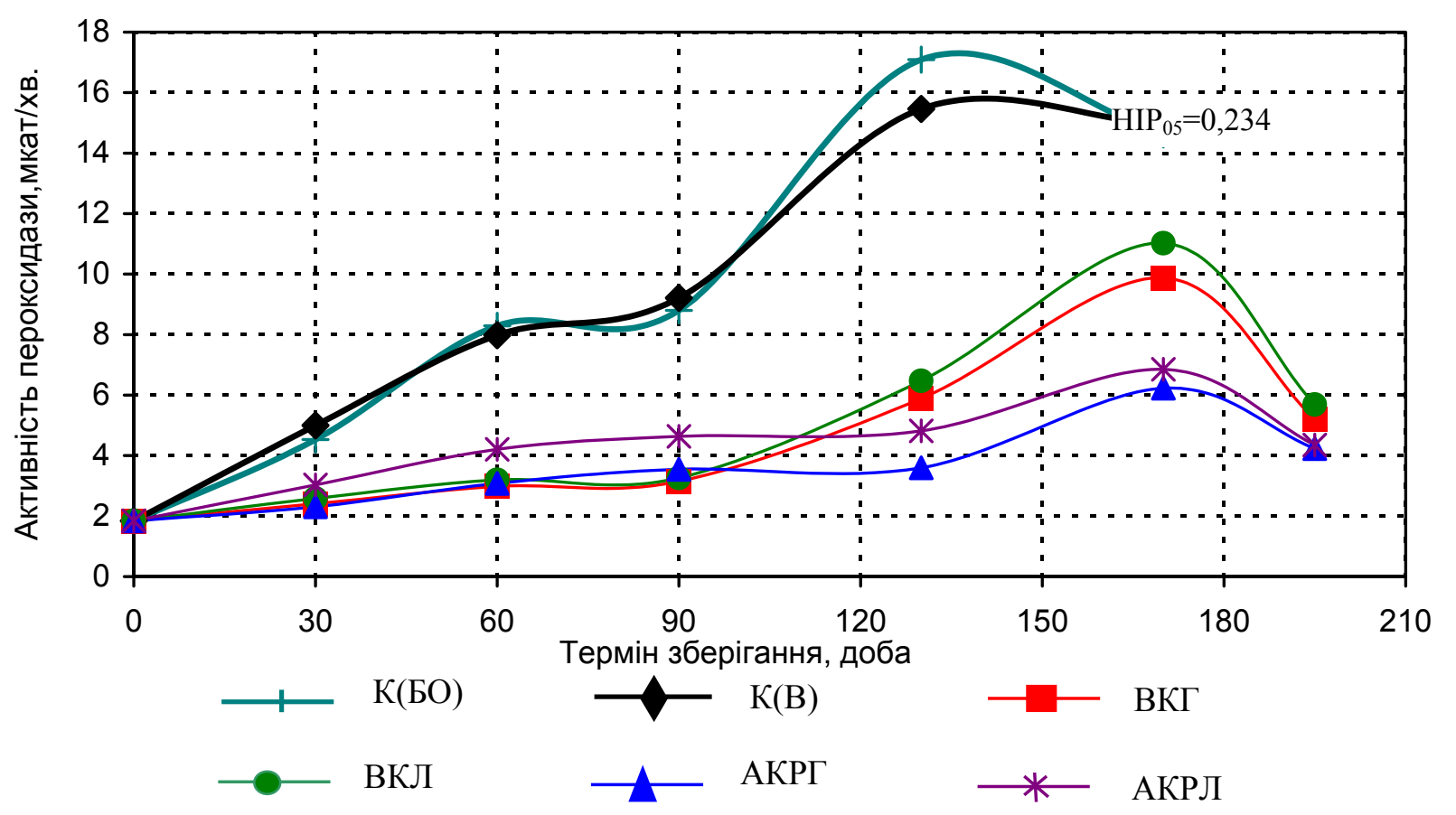

Рис. 4. Пероксидазна активність плодів груші сорту Деканка зимова, оброблених антиоксидантами, мкат/хв

Оброблені плоди показали лабільність ферменту зі зниженням рівня активності в порівнянні $з$ контролем.

Наприкінці зберігання (195-а доба) пероксидазна активність в оброблених плодах була в середньому у 1,6 разу нижча, ніж у контрольному варіанті на 170-у добу зберігання.

На думку В. В. Рогожина [6], значне гальмування активності ферменту композиціями антиоксидантів, пояснюється тим, що в коло пероксидазних субстратів ферменту входять різні функціонально активні речовини, в тому числі й антиоксиданти.

В реакціях індивідуального окислення ці сполуки найчастіше є повільно окислюємими субстратами. Високі концентрації антиоксидантів інгібують пероксидазу як у реакціях індивідуального, так і спільного окислення, здійснюючи таким чином регуляторну функцію.

Поліфеноли, будучи проміжними каталізаторами дихання, окислюючись, переносять водень на інші хімічні сполуки за безпосередньої участі пероксидази.

\section{БІБЛІОГРАФІЯ}

1. Груші свіжі середніх та пізніх термінів достигання. Технічні умови: ГСТУ $01.1-37-162$ : 2004. - [Чинний від 2004-12-29]. - К. : Украгростандартсертифікація, 2005. - $10 \mathrm{c}$.

2. Груші. Зберігання в холодильній камері: ДСТУ ISO 1134:2006 (ISO 1134:1993). - [Чинний
У разі стресових станів (атака патогенів, підвищення температури, водний дисбаланс i тому подібне) характерне підвищення дихального газообміну. У цей час підвищується активність окислювальних ферментів, викликаючи захисні реакції до ослаблення дії стрес-фактора. Так, збільшення активності пероксидази пов'язане 3 утилізацією непотрібних клітині з'єднань (перекиси водню і тому подібне), утворених у процесі посилення дихання пошкоджених тканин. Екзогенне введення біогенних антиоксидантів фенольного типу сприяє цим процесам, підтримуючи енергетичний запас клітин.

Висновок. Таким чином можна зробити висновок, що обробка плодів перед зберіганням композиціями природних антиоксидантів (а особливо комплексами АКРГ та АКРЛ) сприяє гальмуванню окисно-відновних процесів, регулюючи неферментативні та ферментативні системи антиоксидантного захисту. Одночасно зберігається запас тканинних антиоксидантів, що в подальшому впливає на збереженість плодами високої фізіологічної активності.

від 2006-12-11]. - К. : Держспоживстандарт України, 2006. - $10 \mathrm{c}$.

3. Диксон М. Ферменты / М. Диксон, Э. Уэбб. В 3-х томах. - С.-Пб. : ГИОРД, 2003. - 290 с.

4. Котеров А. Н., Никольский А. В. Молекулярный и клеточные механизмы адаптивного ответа 
у эукариот // Укр. биохим. журн., 1999. - Т. 71, №3. - C. 21-23.

5. Миронычева E. C. Обоснование использования антиоксидантных препаратов для длительного хранения плодов яблони//Диссертация на соискание ученой степени кандидата сельскохозяйственных наук. - Ялта, 2002.

6. Рогожин B. B. Пероксидаза как компонент антиоксидантной системы живых организмов /
В. В. Рогожин. - С.-Пб. : ГИОРД, 2004. - 240 с. 7. Фрукти та овочі. Настанова щодо фасування : ДСТУ ISO 7558:2005. - [Чинний від 2008-01-01]. К. : Держспоживстандарт України, 2008. - 6 с. 8. Фрукти й овочі. Фізичні умови зберігання на холоді. Визначання та вимірювання: ДСТУ ISO 2169 - 2003. - [Чинний від 2004-07-01]. - К. : Держспоживстандарт України, 2004. - 6 с. 